\title{
An unusual food plant for Cydia pomonella (Linnaeus) (Lepidoptera, Tortricidae) in Mexico
}

\author{
Alejandro Salinas-Castro ${ }^{1,2}$, María Teresa Mazin-Pérez Sandi ${ }^{1}$, Thalía Ramírez-Reyes ${ }^{1}$, \\ Mauricio Luna-Rodríguez ${ }^{1} \&$ Ángel Trigos ${ }^{1}$
}

\begin{abstract}
'Laboratorio de Alta Tecnología de Xalapa, Médicos \# 5, Col. Unidad del Bosque. C.P. 91010. Xalapa, Veracruz, México. asalinas@uv.mx, mariass01@hotmail.com, tiramirez1906@gmail.com,mluna@uv.mx, atrigos@uv.mx

${ }^{2}$ Facultad de Ciencias Agrícolas, Circuito Gonzalo Aguirre Beltrán s/n, Lomas del Estadio. Xalapa, Veracruz, México.
\end{abstract}

\begin{abstract}
An unusual food plant for Cydia pomonella (Linnaeus) (Lepidoptera, Tortricidae) in Mexico. Larvae of Cydia pomonella (Linnaeus, 1758) were discovered on floral cones of Magnolia schiedeana (Schltdl, 1864) near the natural reserve of La Martinica, Veracruz, México. Magnolia represents an unusual host for this moth species, which is known throughout the world as the "codling moth", a serious pest of fruits of Rosaceae, especially apples. The larvae were identified using taxonomic keys, and identification was corroborated using molecular markers. Further sampling resulted in no additional larvae, hence, the observation was probably that of an ovipositional error by the female, and M. schiedeana is not at risk of attack by this important moth pest.
\end{abstract}

KEYWORDS. Alternative host; codling moth; Insecta; unusual behavior.

As currently defined, the genus Cydia includes approximately 200 described species worldwide (Horak 2006), some of which are serious pests of fruit and legumes. Hosts are primarily in Rosaceae, but some species of Cydia are specialists on Pinaceae, Fabaceae, Fagaceae, Salicaceae, and a few other families of vascular plants (Brown et al. 2008). Among the most notorious pests of pome and stone fruit are C. pomonella (Linnaeus, 1758), (Chen \& Dorn 2009) and Cydia lobarzewskii Nowicki, 1860; among the most important pests of Pinaceae are Cydia toreuta Grote, 1873 and Cydia ingens Heinrich,1926 (Coulson \& Witter 1990; Bédard et al. 2002) and important pests of Fagaceae include Cydia fagiglandana Zeller, 1841 and Cydia splendana Hubner, 1799 (Speranza 1999; Pedrazzoli et al. 2012).

Despite their specialized feeding habits, which often are categorized as oligophagous (Pérez-Contreras 1999), variations in ovipositional patterns are frequently observed in Lepidoptera. These variations are considered "ovipositional mistakes" by some authors (e.g., Thompson \& Pellmyr 1991; Stefanescu et al. 2006; Brown, pers. comm.). This may refer to two main phenomena: (1) oviposition on a host outside the normal range of preferred hosts, and (2) oviposition on a site or substrate that is inappropriate in terms of larval development and/or survival.

Data on oviposition patterns have been used to help understand the evolution of plant-insect relationships (Thompson \& Pellmyr 1991; Janz 2002). These relationships are subjected to a wide range of enviromental factors that are undergoing constant transformations. The response capacity of female Lepidoptera to changes in host availability and changes in habitat structure have ocasionally resulted in permanent host shifts and therefore new plant sanitary problems.
Because there are reports of $C$. pomonella from hosts outside its "normal range," the possibility of a permanent host shift is always present. Cydia pomonella is a cosmopolitan species and one of the most succsesful pests worldwide (Thaler et al. 2008). It is believed to be native to southeastern Europe and southwestern Asia, along with its primary host, apple (Malus domestica, Borkh,1803) (Shel'Deshova 1967; Chapman 1973).

The purpose of this paper is to present the first record of Magnolia schiedeana as a host plant for Cydia pomonella, with the latter identified using morphological and molecular characters.

\section{MATERIAL AND METHODS}

The study was conducted in the Natural Reserve of La Martinica in Veracruz, Mexico, at $19^{\circ} 35^{\prime} \mathrm{N}, 95^{\circ} 56^{\prime} \mathrm{W}$, at $1600 \mathrm{~m}$ above mean sea level, in a location referred to as SINACVER (Sitios de Patrimonio Natural y Cultural de Veracruz). Larvae of Lepidoptera were discovered feeding within flower buds of $M$. schiedeana. They were collected and taken into the laboratory where they were killed and preserved. The larvae were identified using taxonomic keys for Lepidoptera of MacKay (1956), Weisman (1986) and Stehr (1987), along with setal maps of the head capsule and full body and crochets of the third to sixth and tenth abdominal segment.

A specimen previously identified as $C$. pomonella from the entomological collection of LATEX (Laboratory of High Technology of Xalapa) was used as a positive control. The essay consisted of two repetitions with the larvae in study and the control larvae. DNA was extracted using the direct 
method. The first abdominal segment of the larvae was cut with a sterile blade. After a rinsing with distilled water, the segment was placed in a sterile $0.5 \mathrm{~mL}$ eppendorf tube, with $100 \mu \mathrm{L}$ of ultra-pure water for PCR reactions. Tissue was macerated using a sterile pellet in a Qiagen Tissue Lyser tissue disruptor. The upper fluid was withdrawn with a $100 \mu \mathrm{L}$ pipet and inserted in a clean $0.5 \mathrm{~mL}$ eppendorf tube. The resulting material was used as a DNA source.

Specific cpo-D (5'AGCTCTTTTACTTCTTTTATCATT $\left.3^{\prime}\right)$ and cpo-I (5'ATAGGATCACCTCCACCA 3') primers were used to amplify $112-116 \mathrm{bp}$ of the COI gene. Amplification was performed based on the method of Barcenas et al., (2005), with the following modifications: in a $25 \mu \mathrm{L}$ reaction volume containing $2.5 \mu \mathrm{L}$ of $\mathrm{MgCl}_{2} 25 \mathrm{mM}, 2.5 \mu \mathrm{L}$ of buffer $10 \mathrm{X}, 0.625 \mu \mathrm{L}$ of dNTPs $25 \mathrm{mM}, 2.0 \mu \mathrm{L}$ of each primer (10 $\mathrm{Pm} / \mu \mathrm{L}$ of cpo-D primer and $10 \mathrm{pM} / \mu \mathrm{L}$ of cpo-I primer), $0.3 \mu \mathrm{L}$ of Taq DNA polymerase $5 \mathrm{U} / \mu \mathrm{L}, 13.075 \mu \mathrm{L}$ of PCR water and $2 \mu \mathrm{L}$ of template DNA.

The PCR temperature program was as follows: 10 cycles of $94^{\circ} \mathrm{C}$ for $5 \mathrm{~min}, 94^{\circ} \mathrm{C}$ for $1 \mathrm{~min}, 50^{\circ} \mathrm{C}$ for 30 seconds, and $72^{\circ} \mathrm{C}$ for $1 \mathrm{~min}$, followed by 10 cycles of $94^{\circ} \mathrm{C}$ for $1 \mathrm{~min}$, $55^{\circ} \mathrm{C}$ for $30 \mathrm{sec}$ and $72^{\circ} \mathrm{C}$ for $1 \mathrm{~min}$, and finally 10 cycles of $94^{\circ} \mathrm{C}$ for $1 \mathrm{~min}, 60^{\circ} \mathrm{C}$ for $30 \mathrm{sec}$, and $72^{\circ} \mathrm{C}$ for $1 \mathrm{~min}$, with a final extension of $72^{\circ} \mathrm{C}$ for $5 \mathrm{~min}$, programmed in a thermocycler Eppendorf Master Cycler.

The amplification was analyzed in a Bio Rad electrophoresis chamber using $1.8 \%$ agarose gel with 0.5 TBE buffer at 90 volts for 1 hour. Gel was stained with ethidium bromide for $20 \mathrm{~min}$ and revealed in a photo documenter.

\section{RESULTS}

Twelve caterpillars were found feeding on flower buds of Magnolia schiedeana (Fig. 1). The larvae were identified as Cydia pomonella and their setal maps are presented in Figs. 2 and 3. The PCR technique corroborated the identification.

Morphology. The head is yellow-brown, often with a darker brown pattern; the prothoracic and anal shields have dark speckling; and the spines and integument are distinct. The anal comb is absent. The head is hypognathous, with the adfrontals reaching or nearly reaching the epicranial notch, and the epicranial suture is short. There are six stemmata present in an uneven distribution, with the sixth in a more nearby position than the fourth (Fig. 4). The prespiracular group of the prothorax has three setae (Fig. 2). Setae L1 and L2 on abdominal segments 3 to 6 are near and ventral to the spiracle. L1 and L2 on abdominal segment 9 are usually on the same pinaculum, separate from L3, although in some specimens all three setae can be in the same pinaculum. Abdominal segment 9 has D1 and SD1 on same pinaculum (Figs. 2-3).

Molecular markers. The results from the PCR with the specific primers designed to amplify fragments of the COI gene confirmed that the larvae found on M. schiedeana is $C$. pomonella, the gel with the amplification product, with fragments at 115 bps of the COI gene, which according to Barcenas et al. (2005) corroborates a positive result (Fig. 5).

\section{DISCUSSION}

The study site supports one of the few remaining patches of cloud forest in the state of Veracruz, Mexico. The integrity of this ecosystem is at high risk due to human population density in the area and its surroundings, where there is a rapidly increasing exploitation of the forest's natural resources (CONABIO 2010). The expansion of human communities and the constant modification of La Martinica are associated with the growth of the neighboring county of Banderilla and the increase in the areas devoted to cattle grazing

The loss of the forest causes an ever-increasing pressure on C. pomonella populations (possibly established in the area because nearby agricultural practices combine apple and plum growing with short term cycle plants like maize and bean), reducing host availability and altering the topographical structure and architecture (through deforestation and changing of land tenure), both of which may trigger the selection of alternate hosts, such as M. schiedeana and other ornamentals which may be more acceptable for this pest. Variation in ovipositional pattern has been observed in some agricultural pests when the main host is unavailable (Tabashnik 1983). In a study of oviposition by Iphiclides podalirius Linnaeus, (1758), Stefanescu et al. (2006) reported that some females deposit eggs on unusual plants (outside the normal host range), and that this behavior can be attributed to a combination of factors, including low specificity to prefered hosts and a low number (or density) of prefered hosts owing to suburban areas in which the species main hosts were lacking. Studies have also shown that Lepidoptera are highly susceptible to transformations in topographic conditions and are often guided towards hosts by plant height and structure (Singer 2003; Reudler-Talsma et al. 2008). When the appropriate cues are not encountered, alteration in their reproductive habits (mating and oviposition) may occur (Severns 2008).

This unusual behavior (e.g., ovipositon on less than optimal hosts) is difficult to estimate because oviposition does not depend on one factor alone. The other issue is how females chose alternate hosts. Establishing exaclty what leads a female to an alternate host plant is difficult. It may be a combination of factors (Barenbaum 1983; Thompson \& Pellmyr 1991).

Some of the specimens of C. pomonella discovered on M. schiedeana were in the last instars, what may support the hypothesis that female Lepidoptera choose oviposition sites where larvae will most likely develop and survive, although this is not always the case (Thompson \& Pellmyr 1991; Pérez-Contreras 1999). Similarities in chemical compounds between typical and unusual hosts have been studied because chemical reception is an important factor in host selection. Hence the female may be attracted to a new host with compounds similar to that of their typical hosts (Becerra 1997; Becerra \& Venable 1999). Wearing \& Hutchins (1970) proposed that ovipositional behavior in $C$. pomonella is induced by á-farmasene isomers present in 

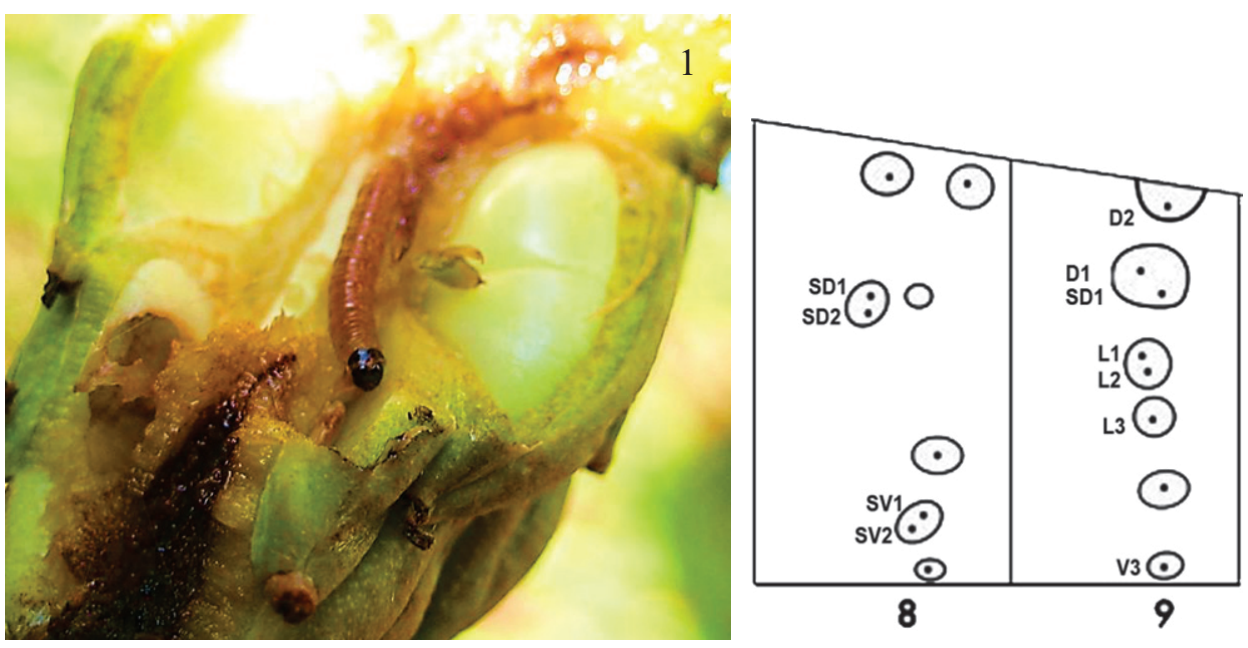

3

4

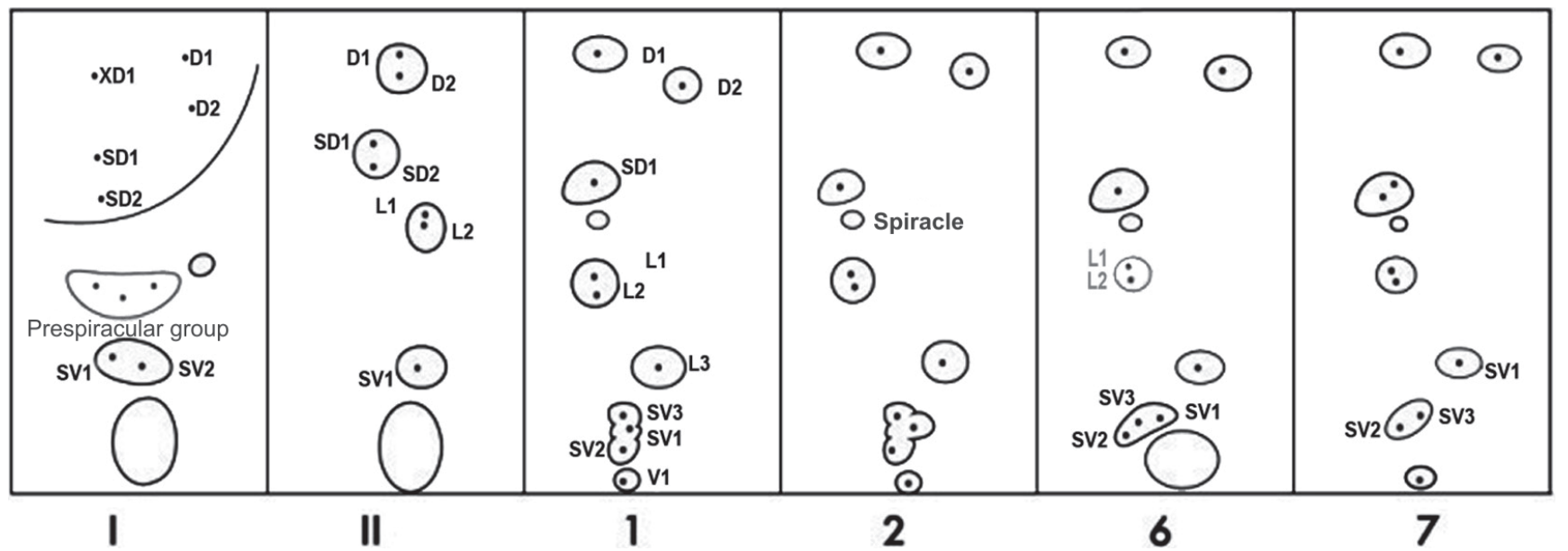

Figs. 1-4. Cydia pomonella. 1. Damage of Cydia pomonella on Magnolia schiedeana. 2. Setal map of segments I, II and 1-7. 3. Setal distribution in abdominal segments 8-9. 4. Stemmata distribution in the head.

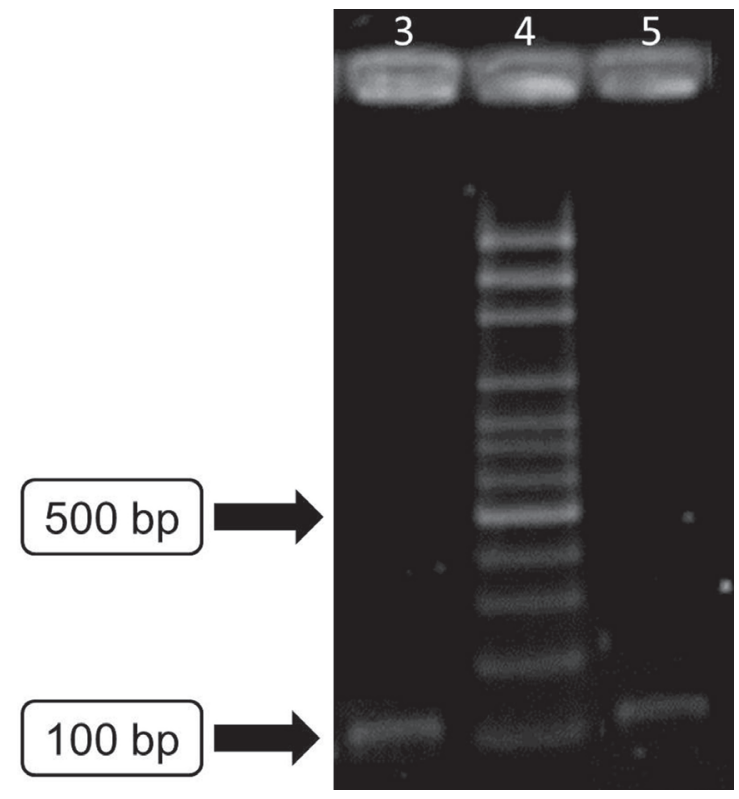

Fig. 5. PCR products in $1.8 \%$ agarose gel stained with ethidium bromide. (3) Positive control of Cydia pomonella at 115 bps. (4) 100 bp Ladder. (5) Cydia pomonella of study at 115 bps. the host fruit. Larvae that hatch on leaves or branches are also attracted to the fruit by the same compound. Presence of this compound in M. schiedeana could have been investigated, but it was not possible to carry out chemical analyses of floral buds of this unusual host.

Despite somewhat specific feeding habits, $C$. pomonella has been reported on hosts outside Rosaceae, including Castanea sativa (Fagaceae), Citrus sp. (Rutaceae), Macadamia sp. (Proteaceae), and Juglans regia (Juglandaceae). Whether unusual host plants are misinterpretations of chemical compounds by females or acts of desperation (absence of primary hosts) leading the female to oviposit on something that has the appropriate leaf texture or plant architecture has been little studied in Tortricidae (Brown 2013, pers. comm.).

When an alternate host plant is widely available and larvae are able to survive and complete their life cycle, these oviposition "mistakes" can lead to permanent host shifts, and C. pomonella may represent such an example. Outside the Rosaceae, C. pomonella has adapted at some point to walnut (Juglans regia), and it is currently an important pest of this plant in South America (Chile and Argentina) (Chapman 1973; Fernández et al. 2010). 
Erratic oviposition may on some occasions have selective advantage, where females with the capacity to choose hosts outside their normal range will have larger chances of survival (Futuyma 1983). Females that lay eggs on more suitable host plants will have a larger number of descendants than females that oviposit on inappropriate host plants in terms of larvae survival and growth (Rausher 1979). The evolutionary process of herbivorous insects is full of beneficial accidents; the term "ovipositional errors" does not imply events to be of no transcendence in plant-insect relationships.

\section{ACKNOWLEDGEMENTS}

We would like to thank Dr. John Brown for his helpful input to this research as well as his time in editing the written material.

\section{REFERENCES}

Barcenas, N.M., Unruh, T.R. \& Neven, L.G. 2005. DNA diagnostics to identify internal feeders (Lepidoptera:Tortricidae) of pome fruits of quarantine importance. Journal of Economic Entomology 92: 299-306.

Barenbaum, M. 1983. Coumarines and Caterpillares; a case for coevolution. Evolution 37: 163-179.

Becerra, J.X. 1997. Insects on plants: Macroevolutionary chemical trends in host use. Science 276: 253-256.

Becerra, J.X. \& Venable, D.L. 1999. Macroevolution of insect plant asociation: the relevance of host biogeography to host affiliation. Proceedings of the National Academy of Sciences of the United States of America 96: 12626-12631.

Bédard, C., Gries, R. \& Gries, G. 2002. Cydia strobiella (Lepidoptera: Tortricidae): antennal and behavioral responses to host and nonhost volatiles. Canadian Entomologist 134: 793-804.

Brown, J.W., Robinson, G. \& Powell, J.A. 2008. Food plant data base of the leafrollers of the world (Lepidoptera:Tortricidae).Available at: http://www.tortricid.net/foodplants.asp (accessed 21 Feburay 2013)

Chapman, P.J. 1973. Bionomics of the apple-feeding Tortricidae. Annual Review of Entomology 18: 73-96.

Chen, M.H. \& Dorn, S. 2009. Reliable and efficient discrimination of four internal fruit-feeding Cydia and Grapholita species (Lepidoptera: Tortricidae) by polymerase chain reaction-restriction fragment length polymorphism. Journal of Economic Entomology 102: 2209-2216.

CONABIO. 2010. El bosque mesófilo de montaña en México: Amenazas y oportunidades para su conservación y manejo sostenible. México, Comisión Nacional para el Conocimiento y Uso de la Biodiversidad, 197 p.

Coulson, R.N. \& Witter, J.A. 1990. Entomología forestal: ecología y control. México, Limusa, 751 p.

Fernández-Górgola, M.C., del Valle-Rivero, C. \& Aybar, S. 2010. Cydia pomonella L. Conocida como gusano de la pera y la manzana. Importante plaga del nogal en la Pcia. de Catamarca. Revista de Divulgación Técnica, Agrícola y Agroindustrial 8: 1-5.

Futuyma, D.J. 1983. Selective factors in the evolution of host choice by phytophagous insects, p. 227-244. In: Ahmed, S. (ed.). Herbivorous
Insects: Host Seeking Behavior and Mechanisms. New York, Academic Press, 257 p.

Horak, M. 2006. Olethreutine moths of Australia (Lepidoptera: Tortricidae). Collingwood, CSIRO, $552 \mathrm{p}$.

Janz, N. 2002. Evolutionary ecology of oviposition strategies, p. 349376. In: Hilker, M. \& Meiners, T. (eds.). Chemoecology of insect eggs and egg deposition. Berlin, Blackwell, $390 \mathrm{p.}$

MacKay, M.R. 1956. Larvae of the North American Olethreutinae. (Lepidoptera). Canadian Entomologist Supplement 10: 1-338.

Pedrazzoli, F., Salvadori C., De Cristofaro, A., Di Santo, P., Endrizzi, E., Sabbatini Peverieri, G., Roversi P.F., Ziccardi, A. \& Angeli, G. 2012. A new strategy of environmentally safe control of chestnut tortricid moths. IOBC/WPRS Bulletin 74: 117-123.

Pérez-Contreras, T. 1999. La especialización en los insectos fitófagos: una regla más que una excepción. Boletín de la Sociedad Entomológica Aragonesa 26: 759-776.

Rausher, M.D. 1979. Larval habitat suitability and oviposition preference in three related butterflies. Ecology 60: 503-511.

Reudler Talsma, J.H., Biere, A., Harvey, J.A. \& van Nouhuys, S. 2008. Oviposition cues for a specialist butterfly-plant chemistry and size. Journal of Chemical Ecology 34: 1202-1212.

Severns, P.M. 2008. Exotic grass invasion impacts fitness of an endangered prarie butterfly, Icaricia icarioides fenderi. Journal of Insect Conservation 12: $651-661$

Shel'deshova, G.G. 1967. Ecological factors determining distribution of Codling moth Lasperyesia pomonella L. (Lepidoptera:Tortricidae) in northern and southern hemispheres. Entomology Reviews 46: 349-361.

Singer, M.C. 2003. Oviposition preference: its definition,measurment and correlates, and its use in assesing risk of host shifts, p. 235-244. In: Cullen, J.M., Briese, D.T., Kriticos, D.J., Lonsdale, W.M., Morin, L. and Scott, J.K. (eds.). Proceedings of the XI International Symposium on Biological Control of Weeds. Canberra, CSIRO Entomology, 648 p.

Speranza, S. 1999. Chestnut pests in central Italy. Acta Horticulturae 494: 417-423.

Stehr, F.W. 1987. Immature Insects. Dubuque, Kendall/Hunt, 729 p.

Stefanescu, C., Jubany, J. \& Dantart, J. 2006. Egg-laying by the butterfly Iphiclides podalirius (Lepidoptera: Papilionidae) on alien plants: a broadening of host range or oviposition mistakes? Animal Biodiversity and Conservation 29: 83-90.

Tabashnik, B.E. 1983. Host Range Evolution: The shift from native legume hosts to alfalfa by the butterfly, Colias philodice eriphyle. Evolution 37: 150-162.

Thaler, R., Brandstätter, A., Meraner, A., Chabicovski, M., Parson, W., Zelger, R., Dalla Via, J. \& Dallinger, R. 2008. Molecular phylogeny and population structure of the codling moth (Cydia pomonella) in Central Europe: II. AFLP analysis reflects human-aided local adaptation of a global pest species. Molecular Phylogeneics and Evolution 48: 838-849.

Thompson, J.N. \& Pellmyr, O. 1991. Evolution of Oviposition Behavior and Host Preferance in Lepidoptera. Annual Review of Entomology 36: 6589.

Wearing, C.H. \& Hutchins, R.F.N. 1973. Alpha-farnesene, a naturally occurring oviposition stimulant for the codling moth, Laspeyresia pomonella. Journal of Insect Physiology 19: 1251-1256.

Weisman, D.M. 1986. Keys for the identification of some frequently intercepted lepidopterous larvae. U. S. Department of Agriculture, APHIS 81-47, 64 p (unpublished material). 